\title{
Kovács Csaba: Egy kudarcra ítélt szakpolitikai beavatkozás a 2008-as világgazdasági válság hitelkárosultjainak megsegítésére
}

\begin{abstract}
A kutatás célja
Elöször szociálpolitikus-hallgatóként, majd antropológiai tanulmányaim lezárásaként vizsgáltam a devizahitelezés kárvallottjainak problémáit és az ennek kezelésére létrejött egyik megoldási kísérletet, az ócsai szociális lakópark működését. Így a kutatás egy szociálpolitikai vizsgálatnak az alkalmazott antropológia eszköztárával történő folytatása. A kutatás során egy teljes évig a terepen tartózkodtam, hogy a különböző időszakok eltérő problémáival találkozzam, és egy teljes ciklust tudjak vizsgálni. A terepmunkát 2013-2015 között végeztem.
\end{abstract}

A tanulmányban nem csupán az akkori állapotot tárom fel, hanem röviden bemutatom a kialakult probléma előzményeit, jogszabályi és gazdaságpolitikai meghatározottságait is.

A kutatás során jogszabályokat, statisztikai adatokat és dokumentumokat elemeztem, valamint különféle interjútechnikákat alkalmaztam, melyeket a terepen történt megfigyelésekkel egészítettem ki. ${ }^{1}$

\section{Jogszabályi keretek}

A 2008-as gazdasági világválság jelentős hatást gyakorolt a magyarországi ingatlanépítésre, vásárlásra, valamint a hitelfelvevők gazdasági, majd ennek következtében társadalmi helyzetének alakulására.

A 90-es évek végére a hitel részaránya az új építések finanszírozásában 10\%-os szint alá süllyedt, a lakásfinanszírozás döntően készpénzalapú volt. Míg 1991-ben a folyósított lakáshitel 20 milliárd forint, addig 1997-ben már csak 9 milliárd forint volt, annak ellenére, hogy a Földhitel- és Jelzálogbank (a továbbiakban: FHB) jelzálogalapú támogatott hiteleket értékesített. 1999-ben kevesebb mint 20 ezer új lakás épült. Az FHB által nyújtott változó kamatozású támogatott hitelek induló kamata, ha az ügyfél az évenkénti kamatváltozást választotta $19,7 \%$, ötéves kamatperiódusnál $16,5 \%$ volt. A nem támogatott, piaci kamatok megközelítették a $25 \%$-ot. ${ }^{2}$

\footnotetext{
${ }^{1}$ A fejezet megírása során az alábbiakban felsorolt hivatalokkal, szervezetekkel, lakosokkal készítettem interjút vagy kértem a megíráshoz szükséges dokumentációkat. Belügyminisztérium Országos Katasztrófavédelmi Főigazgatóság: dr. Bakondi György tüzoltó altábornagy, Ivacs Gyula projektkoordinátor, Veszprémi Beruházási, Vállalkozási és Befektetési Zrt.: Ádám László főmérnök, Ócsa város jegyzője: dr. Szabó György, Ócsa város szociálpolitikai ügyekért felelős ügyintézője: Tresóné Boros Melánia, Ócsa város Családsegítő és Gyermekjóléti Szolgálat: az interjúalanyok anonimitást kértek, Gyáli Kistérség Nevelési Tanácsadó és Logopédiai Szakszolgálata: az alanyok anonimitást kértek, Felsőpakony település lakói.

2 ÁSZ, Állami Számvevőszék (2009): Jelentés a lakástámogatási rendszer hatékonyságának ellenőrzéséről.
} 
2000-ben két lakáshitelezést elösegítő „program” indult: az egyik a jelzáloglevéllel finanszírozott hitelek kamattámogatása (forrásoldali kamattámogatás ${ }^{3}$ ), a másik a kiegészítő kamattámogatás (eszközoldali kamattámogatás ${ }^{4}$ ). A támogatási programok alapgondolata az volt, hogy arra az átmeneti időszakra is szélesebb rétegek számára elérhetővé tegyék a lakáshiteleket, míg az infláció csökkenésével a hitelkamatok megfizethetővé nem válnak. Ezért olyan támogatási konstrukciókat alakítottak ki, melyekben az infláció csökkenésével a támogatás mértéke is csökken. A kezdeti feltételekkel müködő támogatások azonban nem hozták meg a várt eredményt, legalábbis nem indult meg rögtön jelentősebb lakáshitelkiáramlás, ezért a támogatások fokozatos növelése és a jogosultsági kritériumok szélesítése következett be. ${ }^{5}$

2000. február 1-jén lépett hatályba a lakáscélú állami támogatásokat szabályozó 106/1988. (XII. 26.) MT rendelet azon módosítása, amellyel a kormány kiegészítő kamattámogatást biztosított új lakás építése vagy vásárlása esetén, illetve a használt lakásvásárlást jelzáloglevelek kamattámogatásával segítette.

2001. február 1-jétől a lakáscélú állami támogatásokra vonatkozó elöírásokat a 12/2001. (I. 31.) Kormányrendeletben egységesítették, továbbá kibővítették a 2000-ben kialakított támogatási struktúrát a házasok, gyermekes fiatal családok és más arra rászorultak lakásigényének kielégítése céljából (ÁSZ 2009).

$\mathrm{Az}$ 1/2000. (I. 14.) Kormányrendelet az állami támogatások igénybevételének formáiként határozta meg a lakásépítési kedvezményt (a korábbiakban ún. szociálpolitikai kedvezmény), az adó-visszatérítési támogatást, az akadálymentesítési támogatást, a kamattámogatást, az önkormányzatok támogatását, a lakóház-felújítási és víziközmü-támogatást. 2000 februárjától emelkedett a lakásépítési kedvezmény összege; bevezették a lakás vásárlásához, építéséhez, bővítéséhez, korszerüsítéséhez a jelzáloglevéllel finanszírozott hitelek (forrásoldali) kamattámogatását, valamint az új lakás építéséhez és vásárlásához nyújtott kiegészítő (eszközoldali) kamattámogatást. Szabályozták a kamattámogatások mértékét, és a pénzintézettől megvásárolt hitelállomány után felmerült költségek nagyságát, megtérítését [106/1988. (XII. 26.) MT rendelet].

A jelzáloglevéllel finanszírozott hitelek kamattámogatása az induló 3\%-ról 2001-ben 4,5\%-ra, ezt követően 6\%-ra emelkedett 2001 júliusában. 2001 októberében a támogatás maximális mértékét 7\%-ban, 2003 júniusában pedig 10\%-ban rögzítette a kormányrendelet. Ebben az időpontban vezették be az egy támogatott kölcsönre vonatkozó korlátozást is. A kiegészítő kamattámogatású hiteleknél az ügyfél által fizetendő maximális kamat 2000 júniusáig 9\% volt, azt követően $8 \%, 2001$ októberétől pedig 6\%-ra csökkent. A kamattámogatás mértéke 4 százalékpontról 2 százalékpontra mérséklődött 2001 októberében (ÁSZ 2009).

Az e rendeletben foglalt feltételek alapján állami támogatást vehettek igénybe a központi költségvetésből a Magyarország területén lévő lakás építésére, vásárlására, bővítésére, korszerüsítésére, a lakóépületek közös használatú részeinek felújítására, valamint a társulati úton megvalósuló közcélú víziközmü-beruházásokra. Állami támogatáshoz juthattak továbbá

\footnotetext{
${ }^{3}$ A forrásoldali támogatás a lakáshitelek mögött álló jelzáloglevélhez ad kamattámogatást, így teremtve hosszú lejáratú, olcsó forrást a hitelekhez. A jelzálog-kibocsátás joga csak a jelzálogbankokat illeti meg, amelyek szerződéses kapcsolatban állnak a kereskedelmi bankokkal, amelyek a lakáshiteleket nyújtják a lakosság számára, emellett a jelzálogbank maga is folyósíthat hitelt.

${ }^{4} \mathrm{Az}$ eszközoldali kamattámogatást állampapírok referenciahozamához (ÁRH) kötötték, ennek mértékét a program bevezetésekor az ÁRH 4\% pontban határozták meg. Ez azt jelentette, hogy az állampapírkamatok csökkenésével a támogatás mértéke is csökken.

${ }^{5}$ Farkas János, Hegedűs József, Székely Gáborné (2004): Lakáshelyzet, lakástámogatások, 1999-2003.
} 
a települési önkormányzatok bérlakásállományuk növelésére, garzonház, nyugdíjasház vagy idősek otthona létesítésére, lakóépületek energiatakarékos korszerüsítésére, felújítására, városrehabilitáció keretében lakóépülettömbök korszerüsítésére, felújítására, lakbértámogatásra, megyei önkormányzatok idősek otthona, az egyházak nyugdíjasházak vagy idősek otthona létesítésére, valamint a lakhatást szolgáló egyházi ingatlanok korszerüsítésére és felújítására [12/2001. (I. 31.) Kormányrendelet].

Módosult a lakáscélú állami támogatások rendszere. Az egyik legfontosabb változás szerint a kiegészítő kamattámogatás alapján a kölcsön kamatjainak megfizetéséhez az állam az eddigi 10 év helyett 20 évig nyújtott támogatást. A módosítás érintette a gazdasági társaságok és egyéni vállalkozók kölcsönfelvételét is. A 138/2001. (VII. 31.) Kormányrendeletet a már folyamatban lévő támogatási és kölcsönkérelmekre is alkalmazták.

A 2003. júniusi módosítás már főként megszorításokat tartalmazott, melyeket további támogatáscsökkentő intézkedések követtek az év végén. A megszorításokra azért volt szükség, mert a kiáramló hatalmas hitelállomány támogatástartalma túlzott terhet rótt a költségvetésre, és az elörejelzések szerint a hitelezés további növekedésével a jövőben fenntarthatatlanná vált volna a rendszer. ${ }^{6}$

2003 közepén a kamattámogatott hitelek felső határát 15 millió forintra csökkentették. 2003 decemberében a jelzáloglevél-alapú hiteleknél, az új lakás vásárlásánál és építésénél a felvehető hitelösszeg nem változott, azonban használt lakásoknál a támogatott hitel összegét 5 millió forintban maximálták. ${ }^{7}$

2003 decemberében a lakáshitelekhez nyújtott kamattámogatások (jelzáloglevéllel finanszírozott hitelek kamattámogatása és kiegészítő kamattámogatás) alapja és mértéke módosult. A fix állami kamattámogatást mozgórendszer váltotta fel, és ezt követően az állampapír-referenciahozam alakulásától függött a támogatás mértéke. Új lakásnál az állampapír-referenciahozam 60\%-a (jelzálog és kiegészítő kamattámogatás), használt lakásnál pedig 40\%-a (jelzáloglevél kamattámogatás) a támogatás összege. ${ }^{8}$

2001. június 16-tól - a devizatörvény (1995. évi XCV. törvény) és annak végrehajtásáról szóló 88/2001. (VI. 15.) Kormányrendelet értelmében - megszüntek a nemzeti valuta átválthatóságának korlátjai. Az előírások alapján, a forint teljes konvertibilitása mellett, lehetővé vált a gazdasági szereplők számára, hogy egymással szembeni fizetési kötelezettségeiknek külföldi fizetőeszközzel tegyenek eleget. A fenti szabályozás hatályát vesztette 2002. január 1-jétől, ettől az időponttól kezdve ugyanis a 2001. évi XCIII. számú, a devizakorlátozások megszüntetéséről szóló törvény teszi lehetővé a devizabelföldiek, így a vállalkozások számára is, hogy egymás közötti követeléseiket devizában rendezzék, vagyis ne csak a kalkuláció maga, hanem a hozzá kapcsolódó számlázás és pénzmozgás is azonos, forinttól eltérő devizanemben történjen.

Mivel a devizaalapú hitelezés lehetővé vált, és 2003-tól lényegesen kedvezőbb (de kiszámíthatatlanabb) feltételek mellett tudtak az igénylők devizaalapú hitelhez jutni, az ilyen típusú hitelek száma rendkívüli mértékben megnőtt.

A 2008. októberben kezdődő, és 2009-re az euró, a svájci frank és a jen árfolyama a forinthoz képesti drasztikus emelkedésének köszönhetően rendkívüli mértékben nehezítetté vált a hitelállomány visszafizetése. Ugyan a forintalapú hitellel rendelkező hitelesek helyzetét nem

\footnotetext{
${ }^{6}$ Farkas János, Hegedűs József, Székely Gáborné (2004): Lakáshelyzet, lakástámogatások, 1999-2003.

${ }^{7}$ 79/2003. (VI. 6.) Kormányrendelet a lakáscélú támogatások módosításáról.

${ }^{8}$ 221/2003. (XII. 12.) Kormányrendelet a lakáscélú támogatások módosításáról.
} 
befolyásolta az árfolyamváltozás, de az MNB monetáris tanácsának $6 \%$ pontos alapkamatemelése ( $12 \%$ pontra) következtében megemelkedö törlesztörészletek, komoly nehézséget okoztak a hitel visszafizetésében. Nagymértékben megnőtt a törlesztőrészletek 90 napot meghaladó késéseinek száma, ami a bankok számára a hitelszerződések felmondására adott alapot. Ennek mértéke rövid időn belül nagyot ugrott, ami a több tízezerre tehető, várható kilakoltatások számának következtében, az egész társadalmat érintő problémává terebélyesedett.

A 2010 májusában megalakult Fidesz-KDNP-kormány egyik első döntése a kilakoltatási moratórium meghosszabbítása volt. Elöször 2010. december 31-ig, majd ezt követően 2011. április 15-ig és végül 2011. július 1-ig. ${ }^{9}$

A 2010. évi XCVI. törvény meghatározta, hogy a pénzügyi lízingszerződéseknél, a kölcsönöknél és a lakáscélú hiteleknél a pénzügyi intézmény milyen feltételek esetén emelheti a kamatot. Ennek értelmében a pénzügyi intézmények számára kötelezővé tették a devizaközépárfolyam vagy a Magyar Nemzeti Bank hivatalos devizaárfolyamának alkalmazását. A hitelfelvevőnek ingyenes, illetve minimális díj ellenében rendelkezésére állt az előtörlesztés lehetősége. A futamidő alatt, egy alkalommal, a futamidő legfeljebb 5 évvel történő meghosszabbítása díjmentesen lehetővé vált, ha a hitelfelvevő legalább 90 napos késedelemben volt.

Az országgyülés árverezési moratóriumot hirdetett a lakáshitelesek szociális biztonsága érdekében. A törvény legfőbb célja az volt, hogy csak fokozatosan induljon el a tartozások érvényesítése; ne kerüljön a piacra túlzottan nagy lakásállomány, valamint, hogy elkerülhetővé váljon egy, a kényszerintézkedések következtében kialakuló szociális válsághelyzet. A kényszerintézkedési kvóta a 30 millió forintnál alacsonyabb értékü ingatlanokra vonatkozott, a kvóta 2011-ben 2\%, 2012-ben 3\%, 2013-ban 4\%, 2014-ben 5\% volt. $^{10}$

2010-ben az Országgyülés megszüntette az ingatlanjelzáloghoz kötött deviza hitelezését. A devizakölcsönök törlesztési árfolyamának rögzítéséről és a lakóingatlanok kényszerértékesítésének rendjéröl szóló törvényt az országgyülés sürgősséggel tárgyalta és 2011. július 20-án fogadta el. Az eurót $250 \mathrm{Ft}$-on, a svájci frankot $180 \mathrm{Ft}$-on, a jent 2,5 Ft-on rögzítették a programban részt vevő hitelesek részére, maximum 60 hónapig, hogy a jelentős árfolyam-ingadozás hatását átmenetileg tompítsák. Eredetileg a devizaalapú jelzáloghitellel rendelkező természetes személyek 2011. december 31-ig kérhették az árfolyamrögzítést. Ezt meghosszabbították egészen a 2012. év végéig, majd 2013. május 31-ig. ${ }^{11}$

A rögzített árfolyam és a tényleges árfolyam közötti különbséget gyüjtőszámlán vezethette a hitelfelvevő bankja, forintalapú hitelként. A magyar állam készfizető kezesként felel a gyüjtőszámla hitelből eredő tartozások 100\%-áért az árfolyamrögzítés időszaka alatt, ezentúl a gyüjtőszámlából eredő tartozás 25\%-áért, az árfolyamrögzítés lejártát követően is. A résztvevőknek a tőketartozást piaci árfolyamon kell megfizetniük, a gyüjtőszámlán található kamattartozást azonban euróalapú kölcsönnél $250 \mathrm{Ft}$, svájci frankalapú $180 \mathrm{Ft}$, jenalapú kölcsönnél 2,5 Ft árfolyamon kell törleszteni, de csak a tökerészt. A kamatokat 50-50\%-ban a bankok és az állam fizetik. A programban minden jelzáloghiteles részt vehet, akár lakáscélú, akár szabad felhasználású jelzáloghitelt vett fel. Viszont kikötés, hogy három hónapnál

\footnotetext{
9 1994. évi LIII. törvény a bírósági végrehajtásról.

${ }^{10}$ 110/2011. (7.4.) Kormányrendelet.

11 2011. évi LXXV. törvény módosítása, Irományszám. T/5849/22.
} 
nagyobb tartozással nem rendelkezhetnek, illetve a hitel összege nem haladhatja meg a 20 millió forintot. ${ }^{12}$

A rögzített árfolyamon történő végtörlesztés 2011. szeptember 29-től volt kérhető. Eredetileg a program 2011. december 31-én lezárult volna, de ezt meghosszabbították 2012. február 29ig. A törvény lényege, hogy átmeneti időre lehetőséget biztosít az adósok számára, hogy a devizaalapú hitelüket rögzített árfolyamon végtörlesszék egy összegben, forintban. A 2012. évi adótörvények újabb segítséget biztosítottak a hitelfelvevők számára, mivel a munkaadók 7,5 millió forintig adómentes támogatást adhattak dolgozóiknak rögzített árfolyam végtörlesztésére. A Pénzügyi Szervezetek Állami Felügyelete szerint 169256 devizahiteles végtörlesztette a hitelét. ${ }^{13}$

2011-ben az Orbán-kormány otthonteremtési programot indított. A kormányrendelet, ugyan szigorúbb feltételek mellett, de visszaállította a szociálpolitikai kedvezményt, és elindított egy új kamattámogatási rendszert. Ezt olyan családok vehették igénybe, akiknek nem volt ingatlanjuk, új lakást építettek vagy vásároltak, és az elbírálás időpontját megelőzően a szülők egyike legalább 6 hónapos munkaviszonnyal rendelkezett, valamint a család nem rendelkezett köztartozással. ${ }^{14}$

A kormány 2011. augusztus 10-én szociális családiház-építési program indításáról döntött, ${ }^{15}$ majd 2011. június 28-án létrehozta a Nemzeti Eszközkezelő Zrt.-t. A június 28-i kormányhatározat módosításaként augusztus 10-én újabb kormányhatározat jelent meg, melynek lényege, hogy a kényszerintézkedésekre kiválasztott lakásokra olyan vételárat kell kidolgozni, amely a jelzáloghitel-szerződés hitelbiztosíték-mértékéhez igazodik. A 2011. szeptember 26-i kormányhatározatban kihirdették a Nemzeti Eszközkezelő Zrt. által történő megvásárlás feltételeit, a lakásbérleti szerződés megkötésének szabályait. A fő elv, „mind a három érintett fél" (adós, állam, hitelt nyújtó pénzintézet) kiveszi részét a probléma megoldásából. A fizetni nem tudó hitelfelvevő a továbbiakban nem tulajdonosa lakásának, de bérlőként az ingatlanban maradhat, és lehetősége van az ingatlan visszavásárlására. A hitelt nyújtó pénzintézet megkapja a jelzáloggal fedezett követelés jelentős részét, de lemond az azt meghaladó követelésről. Az állam kifizeti az előző pont szerint a vételárat, és így az állam tulajdonába kerül az ingatlan.

A Nemzeti Eszközkezelö Zrt. azokat az ingatlanokat vásárolta meg, amelyekben az adós vagy családja szociálisan rászorult és legalább két gyermeket nevel. Ez a későbbiekben megváltozott, és már egy gyermek nevelése is jogosultsági alapot teremtett. Ezentúl meghatározták az ingatlan forgalmi értékét is, ami Budapesten és a megyei jogú városokban 15 millió forint, más településeken 10 millió forint. A kölcsön összege pedig a forgalmi érték $80 \%$-át (államilag támogatott hitelek esetén a forgalmi érték 100\%-át) nem haladhatja meg. Ezenkívül az adós bejelentett lakhelyének meg kell egyeznie a szóban forgó lakóingatlan címével. Az Eszközkezelö tulajdonába került lakóingatlanok bérleti díját rendkívül alacsony értékben határozták meg, hozzávetőlegesen éves szinten az ingatlan értékének 1,2\%-ban. Fontos kritériumként határozták még meg, hogy az ingatlant 2009. december 31-e előtt kötött hitelszerződés alapján vásárolták meg. A törvény a folyamatban levő végrehajtási eljárás szüneteltetésének lehetőségét is megteremtette. ${ }^{16}$

\footnotetext{
12 2011. évi LXXV. törvény.

13 2011. évi CXVI. törvény.

${ }^{14}$ 257/2011. (XII. 6.) Kormányrendelet.

15 156/2011. (VIII. 10.) Kormányrendelet.

${ }^{16}$ 2011. évi LXXV. törvény (156/2011./VIII. 10. Kormányrendelet) (2011. évi CXXI. törvény).
} 
Ezt követően, annak ellenére, hogy a kormány és a Bankszövetség közötti megállapodás alapján a Nemzeti Eszközkezelö Zrt.-nek 2012-ben 8000 ingatlant kellett volna megvásárolnia, 2012 nyaráig a bankok 500 ingatlant ajánlottak fel, de az értékesítések száma nem érte el a 100 -at sem. ${ }^{17}$

\section{Gazdaságpolitikai keretek}

A Pénzügyi Szervezetek Állami Felügyeletének adatai szerint 2007-ben a háztartások összes adóssága a rendelkezésükre álló jövedelem 51\%-a, míg 2000-ben csupán 10\%-a volt (ÁSZ 2009).

A jövedelem maximális terhelhetősége 2001-2007 között nőtt, ami a bankok hitelezési hajlandóságának növekedését mutatja. 2006-ig a maximális terhelhetőség 50-57\%, 2006 után 70-100\% között mozgott. Fokozódott a hitelintézetek kockázatviselési hajlandósága is, mivel a fedezettségi arány - a nyújtható hitel aránya az ingatlan hitelbiztosítéki értékéhez képest 35-60\%-ról 40-90\%-ra emelkedett. Ha figyelembe vesszük annak lehetőségét, hogy valaki a maximális terhelhetőségének 100\%-ában vehetett fel hitelt oly mértékben, mely a hitelbiztosíték 90\%-ig terjedhetett, világossá válik, hogy e mögött már nem volt a piac változására reagálni, kiegyenlíteni képes tartalék. Ilyen esetekben e kockázat mértéke a hitelintézetek számára legalább annyira irreális volt, mint a hitelt felvevő egyén számára. Az engedélyezett hitelek - támogatott és nem támogatott hitelek - együttes átlagos nagysága, 2001-2007-re közel háromszorosára, 2 millió forintról 5,9 millió forintra nőtt, ami reálértéken 195\%-os emelkedést jelent. Eközben az infláció 38\%-os volt, azaz a hitelfelvételi összeg reálértéken is növekedett. Ezzel párhuzamosan a lakásállomány átlagos lakás-alapterülete is nőtt. ${ }^{18}$

Az államilag támogatott hitelek száma 2001-től 2003-ig folyamatosan nőtt: a 2001-es 21877 darabról 2003-ra 133820 darabra emelkedett. Ezt követően számuk radikálisan lecsökkent: 2004-ben 63419 darab volt, ami 2007-re 19067 darabra változott. Ezzel ellentétes irányt mutatott az állami támogatás nélküli hitelek számának alakulása, ami 2001-2004 között ugyan valamelyest változó tendenciát mutatott, 50-60 000 közötti éves értékkel, viszont 2005-től jelentős növekedés volt megfigyelhető, 2007-ben 111588 darab volt a számuk. ${ }^{19}$

Az államilag támogatott lakáshitelek összege 2001-ben 82,697 milliárd forint volt, s 2003-ban érte el a csúcsát 713,685 milliárd forintos összeggel. Ezt követően az összege radikálisan csökkent, 2008-ban 24,116 milliárd forintra. A devizaalapú lakáshitelezésre 2003-ig nem volt a piacon lehetőség. Ezt követően rendkívül népszerüvé vált ez a lakáshitelezési forma minden kockázata ellenére is. Összege 2004-ben már elérte a 106,391 milliárd forintot. 2005 elején meghaladta az államilag támogatott hitel mértékét, és 2008-ban elérte a 845,705 milliárd forintot. ${ }^{20}$ Ettöl függetlenül folyamatosan jelen volt a piacon az államilag nem támogatott forintalapú lakáshitel, melyet 2001-ben 72,572 milliárd forint értékben folyósítottak. 2002 és 2004 között a folyósítás mértéke éves szinten 120 milliárd forint körül mozgott, majd a devizaalapú lakáshitel növekedésével, e hiteltípus népszerüsége is radikálisan csökkent egészen 2007-ig, mikor összességében 20,861 milliárd forint értékben folyósították ezt a

\footnotetext{
${ }^{17}$ Magyar Bankszövetség (2012) Beszámoló a Bankszövetség 2012. III. negyedévi tevékenységéről, Budapest.

${ }^{18} \mathrm{KSH}$ (2005): Lakásviszonyok az ezredfordulón.

${ }^{19} \mathrm{KSH}$ (2012): Magyar Statisztikai Évkönyv.

${ }^{20}$ KSH: 3.7.4. Lakáscélú hitelek (2001-)(1/2).
} 
hitelfajtát. Az államilag támogatott hitelek esetén az egy hitelszerződésre jutó hitelösszeg 2001-ben 3,8 millió forint volt, ami 2007-re 5,2 millió forintig nőtt. Az állami támogatás nélküli hitelek összege ennél erőteljesebb emelkedést mutatott, míg 2001-ben 1,3 millió forint volt az egy szerződésre jutó hitel mértéke, addig 2007-ben 6 millió forint. ${ }^{21}$

A lakáscélú állami támogatások összesített értéke két részre osztható. A közvetlen támogatások közé a lakásépítési kedvezmény, az adó-visszatérítési támogatás, az akadálymentesítési támogatás, a megelölegezett kedvezmény (1994-ig), a fiatalok otthonteremtési támogatása és a megelőlegezett kedvezmény beváltása tartozott. Ennek összege 2000-ben 31,302 milliárd forint volt, 2003-ban már 41,968 milliárd forintot tett ki és 2005-ben érte el legmagasabb összegét 67,179 milliárd forinttal, majd onnan csökkent le 2007-re 52,948 milliárd forintra. A másik nagy csoport, a kamattámogatás és egyéb költségek összesítése. ${ }^{22}$ Mindez 2000-ben 17,221 milliárd forint terhet rótt a költségvetésre és 2005-ben érte el csúcspontját, 178,726 milliárd forinttal. Ezt követően kismértékben csökkent, majd 2007-ben 160,897 milliárd forintot jelentett. A két fent megnevezett lakáscélú állami támogatás együttes értéke 2000-2005 között folyamatosan nött, 48,524 milliárd forintról 245,906 milliárd forintra, majd ezt követően kismértékben csökkent. ${ }^{23}$

2000-2008 között a költségvetés lakáscélú kiadása összesen 1469 milliárd forintot tett ki. Az engedélyezett támogatott lakáshitelek száma 2001-2008 között 404000 darab volt. A támogatott hitelállomány dinamikus emelkedése hosszabb távra (10-15 évre) determinálta a költségvetés lakástámogatási kiadásait. A kamattámogatás 2000-ben a költségvetés 0,1\%-át tette ki, ez 2008-ra 0,7\%-ra emelkedett, de 2005-ben már 0,8\% volt. A 2003. évi államilag támogatott hitelek kedvezményének szükítése, és egyúttal a nagyon kedvező devizahitelek megjelenése, már nem tette versenyképessé az államilag támogatott kamattámogatási rendszert. A 2004-től érvényes referenciahozamok mellett a kamattámogatásos hitelek esetében az ügyfél által fizetendő kamatok magasabbak voltak, mint a devizahiteleknél. ${ }^{24}$

Érdemesnek tartom még megvizsgálni az euró és a svájci frank kamatlábainak, hitelköltségmutatójának és árfolyamváltozásának alakulását is az általam vizsgált időszakban. Fontosnak tartom pontosan tisztázni, hogy az általam vizsgált probléma kiindulópontjaként szolgáló megemelkedett törlesztörészletek hogyan járultak hozzá a kialakult helyzethez.

2005. január és a válság kezdete, 2008 októbere között, az eurókamatláb a változó kamatozás, vagy legfeljebb egyéves kamatfixálású lakáshitelek esetén 4,92 és 4,87 érték között mozgott. 2008 novemberében jelentős emelkedés következett be, ami 7,5\%-ra növelte az értéket, ami a devizaalapú hitelezés megszünéséig, 2010 júniusáig nem változott. Érdekes, hogy eközben hogyan alakult a háztartásoknak nyújtott euró lakáscélú hitelek átlagos hitelköltség-mutatója. A változó kamatozás vagy legfeljebb egyéves lakáscélú hitelek esetén, 2005. január és 2008 októbere között a mutató értéke 7,28 és 6,28 értékek között mozgott. Nagy ugrás látható 2008 novemberében, amikor 10,1\%-ra emelkedett, és ezen érték körül mozgott egy éven keresztül,

\footnotetext{
${ }^{21}$ KSH: 3.7.4. Lakáscélú hitelek (2001-)(2/2).

${ }^{22}$ Folyósítási költség (másfél és 3\%), garancia érvényesítése, energiamegtakarítási támogatás, fix kamatok kiegészítése, betétesek, ifjú házasok kölcsöne, kiegészítő kamattámogatás, forgóeszközhitelek támogatása, törlesztési támogatás (1989-1993), kamattámogatás települési önkormányzatoknak, jelzáloglevelek kamattámogatása, lakótelepi program, hitelintézetek által igénybe vett előleg, OTP-hitel-hátralékkezelés, megelölegezett kedvezményes kamatplusz költsége, martinsalakos épület és a tiszai árvízkárosultak, víziközmü kamattámogatása, egyéb kamattámogatás, megvásárolt hitelállomány 0,5\%-os költségtérítése, kamattérítés, tájékoztatási költség és függő tétel.

${ }_{23}$ ÁSZ, Állami Számvevőszék (2009): Jelentés a lakástámogatási rendszer hatékonyságának ellenőrzéséről.

${ }^{24}$ ÁSZ, Állami Számvevőszék (2009): Jelentés a lakástámogatási rendszer hatékonyságának ellenőrzéséről.
} 
de 2009 októberétől egészen a devizahitel megszünéséig folyamatosan csökkent, és 2010 júniusában a mutató 7,54-es értéken zárt. ${ }^{25}$

A háztartásoknak nyújtott svájci frank lakáscélú hitelek átlagos kamatlába, a változó kamatozású vagy legfeljebb egyéves kamatfixálású, szabad felhasználású jelzáloghitelek esetén, 2005. január és 2008 októbere között 4,89 és 5,91 közötti értéktartományban volt és ezt követően 2008 novemberétől 2010 áprilisáig sem változott jelentősen.

Az MNB nyilvánosan elérhető adatbázisában nem szerepel átlagos kamatláb a svájci frankra vonatkozóan, csak átlagos évesített kamatláb. Ez az euró és a svájci frank közötti összehasonlítást nem teszi lehetővé. A háztartásoknak nyújtott svájci frank lakáscélú hitelek átlagos hitelköltség mutatója, a változó kamatozású vagy legfeljebb egyéves kamatfixálás a lakáscélú hitelek esetén, 2005 januárja és 2008 októbere között 6,06 és 7,24 értéktartományon belül mozgott. Ezt követően a devizahitelek megszüntetéséig kismértékben csökkent. ${ }^{26}$

2005 januárjában 246 forintba került 1 euró, és egész évben nagyjából e körül az érték körül mozgott. 2006 közepétől lassú emelkedés volt megfigyelhetö, ami 2006 szeptemberére érte el a 274 forintot. Ezután kisebb csökkenés következett, 2008 júliusára 231 forint volt 1 euró. 2008 októberében ismét emelkedés jött, majd 2009 januárjában drasztikus növekedés, 2009 márciusában 304 forintra emelve 1 euró árát. Kisebb gyengülés után 2009 májusától 2011 augusztusáig 287 forint körül mozgott a középárfolyam, melyet újabb drasztikus emelkedés követett. 2012 januárjában 307 forint, 2012-ben pedig 280-285 forint között mozgott az árfolyam. $^{27}$

A svájci frank esetében 2005 januárjában a középárfolyam 159 forint volt. Lassú, folyamatos emelkedés következett 2006 szeptemberéig, majd 2007 júliusában 148 forintba került 1 svájci frank, amely 2008 októberéig 150 forint körül maradt. 2008 októberében markáns változás következett be, 169 forintra nőtt a középárfolyam, majd kisebb ingásokkal, de folyamatosan emelkedett. 2012 januárjában 253 forint lett 1 svájci frank ára, ami némi gyengülést követően 2012 októberében 233 forint lett. ${ }^{28}$

2011-ben a magyar lakosság lakáshitel-állománya 4222 milliárd forint volt. 2002-2010 között a devizahitelek összege 140-szeresére növekedett. A PSZÁF adatai szerint 2011. június végére 1225419 lakossági jelzálogfedezetü szerződést kötöttek. Ezek negyedénél már volt valamilyen késedelmi probléma, több mint egytizedüknél (kb. 142 000) 90 napon túli elmaradás volt tapasztalható. A PSZÁF becslése szerint több mint 301000 késedelmes tartozás közül mintegy 262 000, a mintegy 14200090 napon túli tartozásból pedig, 123000 a devizaalapú hiteltartozás. ${ }^{29}$

Az ingatlanárveréseket követő kilakoltatások száma nem nőtt drasztikusan ebben az időszakban. A Magyar Bírósági Végrehajtó Kamara statisztikái alapján, 2012 harmadik negyedévében a kamarához beérkező ügyek száma 142723 volt; a végrehajtási ügyek többsége nem érte el a 100000 forintos összeghatárt. Ingatlanárverésre 2012 első három negyedévében 620 alkalommal került sor, ezek nem minden alkalommal voltak lakóingatlanok. A törvény által meghatározott aktuális évre vonatkozó ingatlanárverések

\footnotetext{
${ }^{25} \mathrm{MNB}$, Adatok, idősorok, VII. árfolyam.

${ }^{26} \mathrm{MNB}$, Adatok, idősorok, VII. árfolyam.

${ }^{27} \mathrm{MNB}$, Adatok, idősorok, VII. árfolyam

${ }^{28} \mathrm{MNB}$, Adatok, idősorok, VII. árfolyam.

${ }^{29}$ MNB: Idősorok.
} 
nagyon kis száma valósult meg, mivel az ügyek többnyire az árverések előtti utolsó időszakban megoldódtak. ${ }^{30}$

Lényeges változást okozott a lakáshitelek számának változásában az euró, a svájci frank és a jenalapú kölcsönszerződések kedvezményes végtörlesztése. 2011. október 30-a és 2012. február 29-e között összességében 5736 darab euróalapú devizakölcsönt, 473683 svájci frankalapú devizakölcsönt, valamint 10140 jenalapú kölcsönt, összesen 489559 kölcsönt végtörlesztettek. Aktuális árfolyamon összességében 3583,910 milliárd forint értékü végtörlesztés történt, ami a végtörlesztési árfolyamon 2607,177 milliárd forintot tett ki. A devizaalapú kölcsönök kedvezményes végtörlesztésére felvett és folyósított forinthitelek darabszáma 109997 volt, ami 628666 millió forint hitelfelvételt jelentett. ${ }^{31}$ A visszafizetések átlagos összege a rögzített végtörlesztési árfolyamon 5,8 millió forint volt.

A végtörlesztési konstrukció a hitelintézeteknek összességében, 370 milliárd forint bruttó veszteséget okozott. Ennek mintegy 30\%-át a hitelintézetek a 2011. évi bankadóból leírhatták, így a teljes piaci veszteség nettó 260 milliárd forintot tett ki. ${ }^{32}$

\section{Szociális családiház-építési program Ócsán}

A programot Magyarország kormánya indította el három, később többszörösen módosított kormányrendelettel. (265/2011. (XII. 13.) Korm. rendelet, 1434/2011. (XII. 13.) Korm. határozat, a Kormány 431/2012. (XII. 29.) Korm. rendelete, módosítva: 156/2011. (VIII. 10.) Korm. rendelet, 1279/2011. (VIII. 10.) Korm. határozat). A program célja, hogy a már kényszerértékesítésen, kilakoltatáson túl vagy alá eső helyzetü hitelkárosultak és családjuk lakhatását megoldja. A program során az 1940-es évek eleji ONCSA-program mintájára úgynevezett mintafalut kívántak létrehozni. ${ }^{33}$

A projekttel kapcsolatos gondokat két, egymástól teljesen elkülönülö problémacsoportra kell bontani. Az első szakasz maga az alapprogram, ami szociális családi házakat hozott létre rászorulók részére. A második szakasz a program kivitelezésére létrejött közfoglalkoztatási alapból induló munkaprogram. A Belügyminisztérium Országos Katasztrófavédelmi Főigazgatóság tájékoztatása szerint a program koordinálását a főigazgatóság részéről két fő végezte, Budapest Főváros Kormányhivatal Munkaügyi Központjával együtt, közel 20 településről tudták megszervezni az építkezésen dolgozó átlag 120 föt, melynek egyharmada szakmunkát, kétharmada segédmunkát végzett. Eredetileg 541 fö, 201 szakmunkás és 340 fö segédmunkás közfoglalkoztatott létszám kiközvetítésére adott be igényt a BM Országos Katasztrófavédelmi Főigazgatóság, ami a valós igény közel egyharmada volt. ${ }^{34} \mathrm{~A}$ kiértesítettek 25-30\%-a dolgozott összességében az építkezéseken. A többség különbözö okokból nem felelt meg vagy nem akart a közfoglalkoztatásban részt venni. Nehézséget okozott a megfelelő számú szakmunkás közfoglalkoztatásba állítása. A vállalkozói szerződés

\footnotetext{
${ }^{30}$ MBVK, Magyar Bírósági Végrehajtói Kamara (2012): III. negyedéves jelentés.

${ }^{31}$ PSZÁF (2012): Gyorselemzés a végtörlesztésröl.

${ }^{32}$ PSZÁF (2012): Gyorselemzés a végtörlesztésröl.

${ }^{33}$ A fejezet megírása során az alábbiakban felsorolt hivatalokkal, szervezetekkel, lakosokkal készítettem interjút vagy kértem a megíráshoz szükséges dokumentációkat: Belügyminisztérium Országos Katasztrófavédelmi Főigazgatóság: dr. Bakondi György tüzoltó altábornagy, Ivacs Gyula projektkoordinátor, Veszprémi Beruházási, Vállalkozási és Befektetési Zrt.: Ádám László főmérnök, Ócsa város jegyzője: dr. Szabó György, Ócsa város szociálpolitikai ügyekért felelős ügyintézője: Tresóné Boros Melánia, Ócsa város Családsegítő és Gyermekjóléti Szolgálat: az interjúalanyok anonimitást kértek, Gyáli Kistérség Nevelési Tanácsadó és Logopédiai Szakszolgálata: az alanyok anonimitást kértek, Alsópakony település lakói.

${ }^{34}$ BMK Zrt. (2012): Ajánlattételi Dokumentáció, Szociális Családiház-építési Program.
} 
alapján a vállalkozó vállalkozási díjából levontak a közfoglalkoztatottak munkavégzése után, szakmunkás esetén nettó 4500 forintot, segédmunkás esetén 3500 forintot. Az összes egyéb járulékos költséget a közfoglalkoztatási alapból fizették. A megrendelő és a vállalkozó képviselője szerint, figyelembe véve a közfoglalkoztatottak által elvégzett munka minőségét és hatékonyságát, a tipikus munkavégzés alapján felvett munkavállalók, az előbb ismertetett paraméterek alapján költséghatékonyabb megoldást jelentettek volna. Nagyon nehéz volt megszervezni a közfoglalkoztatottak utaztatását is.

A program Ócsa külterületén, az M5-ös autópálya mellett, Alsópakony közelében valósult meg. A terület 2011-ig mezőgazdasági müvelés alatt állt, korábban nem voltak itt épületek. Alsópakonyban, a program helyszínétől 150 m-re található egy 30-35 házból álló telep, ahol a rendszerváltás időszakában bezárt Felsőbabádi Állami Gazdaság működött korábban. A lakosok a munkahelyek megszünését követöen is ott maradtak.

A területi elhelyezkedéséből adódóan a szociális gazdaság lakóépületeiként jól müködő egységet képezhetne a lakópark, de ehhez hiányzik maga a szociális gazdaság, amelyet mintha egyszerüen elfelejtettek volna megtervezni és kivitelezni.

A kutatás helyszíne Ócsa település központjától 6, a szélétől úgy 3,5 kilométerre található. A kutatás idején Ócsán egy iskola, két óvoda müködött, bölcsőde nem volt. ${ }^{35} \mathrm{Az}$ iskola vezetése szerint az iskolába a kutatás időszakában 601 gyermek járt, a megengedett kapacitás 827 fó volt, tehát az iskola be tudta fogadni az új beköltözö gyerekeket. A két óvoda és a kutatás időpontjában épülő bölcsőde csak részben tudta fogadni az újonnan beköltöző gyerekeket. A fontosabb intézmények, az orvosi rendelö, az iskola, az óvoda, a polgármesteri hivatal a város központjában találhatók.

A kutatás helyszíne és Ócsa város között ritka (6 alkalom/nap) volt a tömegközlekedés. Üllő és Ócsa között ugyan járt busz, de ez a buszjárat nem állt meg Alsópakonyban. Ócsa város egy iskolásokat szállító buszjáratot üzemeltetett, amely Alsópakonyból reggel 6.39-kor indult, és délután az iskola befejezésével hozta vissza a gyerekeket. A kutatás időpontjában Alsópakony, a Szociális lakópark és Ócsa város között a gyalogosforgalom számára nem volt járda, bicikliút kiépítve. A projekt helyszínére elektromos közmühálózatot építettek és kialakították a szennyvíz elvezetését is. A projekt 500 különálló ház megépítését célozta meg, ebből a kutatás időpontjáig 80 épület készült el.

Pályázat útján terveztették meg a házakat. Tervek készültek 40, 50, 60, 70, 80 négyzetméteres épületekre is. Külön megtervezték a telepet blokktéglára, készházra és vályogházra is, végül a blokktéglás kivitelezés mellett döntöttek. A terveknél fontos szempont volt a régi magyar falusi jelleg megjelenítése, ennek megfelelően a külső megjelenésben a fa dominál. Minden ház egyéni homlokzatfelületet kapott.

A projekt első fázisa az 5-12/80-4699/2012 vállalkozói szerződés alapján 1858544763 forint + áfa vállalkozási díjból valósult meg. Ebböl $50 \mathrm{db} 50$ négyzetméteres, $20 \mathrm{db} 60$ négyzetméteres és $10 \mathrm{db} 70$ négyzetméteres lakás épült meg összesen 4400 négyzetméteren. Az összes költséget figyelembe véve 1 négyzetméter új építésü lakóingatlan 536443 forintba került. Ugyanekkor Ócsa településen a használt ingatlanok négyzetméter ára 130-170 000 forint között mozgott, Pest déli kerületeiben is 180-220 000 forint közötti értéken lehetett használt ingatlanokat vásárolni. Egy más koncepción alapuló programban ugyanebböl az összegből 2,5-3-szor annyi, lényegesen jobb adottságokkal rendelkező ingatlan vásárlására lett volna lehetőség, amelyből hasonló módon, bérlakásokat lehetett volna üzemeltetni.

\footnotetext{
${ }^{35}$ A megjegyzés a 2013-as évre vonatkozik.
} 
A projekt helyszínét rosszul választották ki. A közvetlen környezet rehabilitációjának elmaradása, illetve a rendezetlen tulajdonviszonyok a beruházás területén kívüli földterületek esetén közvetve befolyásolták a beruházás kivitelezését. Az Ócsa várostól teljesen elkülönülő településrészen lakók, beköltözők integrálása a településbe szinte lehetetlennek mutatkozott.

A megoldatlan buszközlekedés a város és a településrész között hátráltatta az ott lakókat mindennapi életükben is. A buszközlekedéshez nélkülözhetetlen körforgalom megtervezésének elmulasztása és az arra elkülönített pénzügyi keret hiánya következtében az valószínüsíthető, hogy rövid időn belül a probléma nem is fog megoldódni (a katasztrófavédelem és a Volán busztársaság tájékoztatása alapján jelenleg busz csak kiépített buszfordulóban fordulhat meg).

Az előkészítési és engedélyezési eljárás csak a már megépült 80 házra készült el, a teljes beruházásra nem.

A kivitelezés közben észlelt problémák kezelése az engedélyezési eljárásban is változtatásokat igényelt volna, ami maga után vonta volna a közbeszerzési eljárás módosítását is. Mivel kormányrendelet született a kivitelezés befejezésének időpontjáról, ezért hiába látta a megrendelő és a vállalkozó is a felsorolt problémák jelentős részét, a módosítás 5-6 hónapot vett volna igénybe és erre nem volt lehetőség.

A használatbavételi eljárást követően a lakópark a Nemzeti Eszközkezelő Zrt. tulajdonába került. A bérlők részéről az ingatlanban és körülötte minden átépítéshez, hozzáépítéshez és a jelenleg már ismert hiányosságok egyedi korrigálásához az eszközkezelő hozzájárulása szükséges. A bérleti viszonyból adódóan nem látható, hogy miért érné meg a bérlőnek a hiányosságokat pótolni, megoldani saját pénzéből.

A helyszín kiválasztásakor nem történt egyeztetés a helyi szakmai szervezetekkel, például a település szociálpolitikáért felelős előadójával, a családsegítővel, a nevelési tanácsadóval, az iskolával, az óvodával. A településen dolgozó két szociális munkást, annak ellenére, hogy a beköltözés már javában folyt, sem a lakóparkkal, sem az ott élőkkel kapcsolatos információkkal nem látták el. Új szociális munkást sem vettek fel, holott a két szociális munkás várható feladata meghaladta a kapacitásaikat, már így is a munkaidejükön túli feladatok elvállalására kényszerültek.

A településen további nehézséget okoztak a rossz koncepció alapján megterveztetett ingatlanok, a be nem tervezett és ki nem épített kutak, melyek nélkül az öntözés csak drága vezetékes vízből oldható meg. A kutak építése 2014-ben, az első beköltözéseket követően egy évvel elkezdődött, de nagyon lassan haladt.

A házak fütése kizárólag fatüzelésű kályhákkal történik, melyekkel kapcsolatban a vállalkozót képviselő építésvezető arról tájékoztatott, hogy legalább 3 óránként kell pótolni a fát, tehát a folyamatos fütés miatt a családból valakinek otthon kell maradni, és csak otthon végezhetö munkát tud majd vállalni. A fütés eredményeként a házakban nincs állandó hömérséklet, a napi hőingadozás 6-8 fok. A tüzifa tárolásához szükséges helyiség kiépítése csak a beköltözések után valósult meg, a kerti szerszámok tárolásához szükséges helyiség kialakítása pedig nem történt meg.

A házak $10 \mathrm{~cm}$-es hőszigetelő réteget kaptak, ami miatt csak $\mathrm{C}$ besorolásúak, a magasabb besorolás elérése, plusz 5-10 $\mathrm{cm}$ hőszigetelö anyag, minimális többletköltséget jelentett volna. A csapadékvíz tárolása sem megoldott és nem is megoldható az épületek jelenlegi 
állapota miatt. Mivel a földgázhálózatot nem építették ki, elektromos árammal kell a meleg vizet előállítani, ami a meleg víz előállításának legdrágább módja.

Az „arra érdemesek”, vagyis azon hitelkárosult családok számára, akik beköltözhettek, a beköltözés feltételei között szerepelt, hogy a család felnőtt tagjai a munkájukat nemrég veszítették el, vagy ha volt is munkájuk, dolgozni képes és hajlandó egyének legyenek. Ugyanakkor Ócsa városában a munkanélküliség aránya magasabb volt az országos átlagnál. A környékbeli településeken nem volt olyan új beruházás, amely az így mesterségesen keletkező többletmunkaerő-kínálat felvételére képes lett volna. Budapest déli része, a már említett 6 kilométeres gyaloglást követően, Ócsa központjából közel egy óra alatt közelíthető meg.

Az idénymunka lehetősége is nagyon korlátozott. A szabályozásig a Duna árterülete volt a terület, ennek megfelelően cseresznye- és szilvaültetvények vannak a környéken, melyeknek szüretelése igényel ugyan nagyobb számú munkaerőt, de ezt a környékbeli gyümölcsösök tulajdonosai Romániából szervezetten idehozott munkásokkal oldották meg, akiknek külön munkásszállást is építettek.

A beköltözött lakók véleménye szerint a helyi önfenntartás lehetősége, zöldség- és gyümölcstermesztésen, valamint kisállattartáson keresztül, a föld minősége és a locsolás megoldatlansága miatt nem lehetséges. A területen az elmúlt időszakban homokbánya müködött. A beköltözők nem érdekeltek abban, de lehetőségeik sem engedik meg, hogy a föld minőségét mütrágyázással vagy bármi más módon megpróbálják földmüvelésre alkalmassá tenni.

\section{A település lakói: a Nemzeti Eszközkezelő Zrt. által, a beköltözőkkel kapcsolatban felállított kritériumok}

A beköltözés feltétele volt, hogy a devizában eladósodott lakóingatlana kényszerértékesítés, árverés alatt álljon, vagy már elárverezték, vagy egy éven belül el fogják árverezni. Szintén feltétel volt, hogy a családban legalább egy kiskorú vagy 25 év alatti, családi pótlékra jogosult, nevelési, oktatási, felsőoktatási intézményben tanuló gyermek legyen. Továbbá más lakhatást biztosító használati joggal ne rendelkezzen, vállalja a kertmüvelést a részbeni önfenntartás érdekében, és végezetül az ingatlanjelzálog-hitelszerződés megkötésekor megállapított forgalmi értéke nem haladhatta meg Budapesten és a megyei jogú városokban a 25 millió forintot, más településeken a 20 millió forintot [431/2012. (XII. 29.) Kormányrendelet].

A kutatás során még csak 42 házba költöztek be a lakók. A szociális munkásokkal történt beszélgetés alapján ez sem ment könnyen. A megadott pályázati feltételeknek ugyan sokan megfeleltek, de azt a döntést, hogy felszámolják az eddigi életük minden biztos pontját, a teljes kapcsolati hálójukat és belevágjanak valami bizonytalanba, ráadásul a megszokott környezetüktől távol, akár több száz kilométerre, ezt nagyon kevesen vállalták. Egy országos lefedettségü karitatív szervezet és a szociális és nyugdíjpolitikáért felelős miniszterrel kötött megállapodás alapján a Nemzeti Eszközkezelő Zrt. pályázatot írt ki a lakóparkba költöző lakók kiválasztására. A kiválasztást a karitatív szervezet munkatársai végezték. A pályázat célja az volt, hogy a szociálisan hátrányos helyzetü, eladósodott, lakásukat elvesztő emberek a lakhatásuk biztosítását visszanyerjék, és megerősítsék társadalmi státusukat. A pályázat felhívásából idézve: „További célkitüzés, hogy az intézkedés eredményeként egy új kezdet lehetősége teremtődjön meg az eladósodott családok számára, olyan formán, hogy az alacsony rezsiköltségek mellett a továbblépés lehetősége is megmaradjon.” (Pályázati felhívás 2013. 01. 15.) A pályázók között rangsort állítottak fel. A rangsorban elönyt élveztek azok a 
családok, ahol a családnak legalább az egyik tagja keresőtevékenységet folytatott. A rangsor szerint környezettanulmányt készített a karitatív szervezet mindaddig, amíg ki nem választották a 80 új ház lakóit.

A kiválasztási folyamat során feltérképezték a támogatói kapcsolatokat; a családok erőforrásait és jövedelmi viszonyait; a munkaerőpiaci helyzetet, a munkavégző képességet, a munkatapasztalatot; az élethelyzetböl fakadó személyes kötelékeket (a család helyzetét a közösségben); a célokat, törekvéseket, elképzeléseket, valamint a közfoglalkoztatottságban való részvételi hajlandóságot (Pályázati felhívás I., 2013).

A környezettanulmány vizsgálatának célja: „Olyan beköltöző családok kerüljenek kiválasztásra, akik az újrakezdésben, a tartós megoldásban motiváltak, illetve foglalkoztatottak, vagy munkájukat még nem olyan régen vesztették el, így elhelyezkedési esélyeik jók. Ezeknek a családoknak egyrészt alkalmazkodniuk kell majd az új lakókörnyezethez, másrészt elegendő jövedelemmel kell rendelkezniük ahhoz, hogy önmagukat fenntartsák, esetleg adósságaikat rendezni tudják." (Pályázati felhívás I., 2013)

A pályázat nem hozta meg a várt sikereket, még megközelítőleg sem tudták feltölteni az újonnan épült lakóparkot lakókkal. Ezért, hasonló formában, új pályázatot írt ki a Nemzeti Eszközkezelö Zrt. Igaz, valamelyest könnyítettek a feltételeken, de elvárásként megjelent, hogy a sikeres pályázat után a beköltöző családnak vállalnia kell a kertművelést a részbeni önfenntartás érdekében, és a közösségi normák betartását (Pályázati felhívás II., 2013).

Ennek a pályázati körnek a lezárulásával még mindig csak félig sikerült a megépült ingatlanok feltöltése. Ezt követően, már a karitatív szervezet közremüködése nélkül, a Nemzeti Eszközkezelő Zrt. a maradék ingatlanok hasznosítása céljából még három pályázati felhívást indított 2014. január 15. és 2014. április 15 . között. ${ }^{36} \mathrm{~A}$ pályázatban a pályázók közötti sorrendiség szempontjai a következők voltak: rendelkezik-e már a Nemzeti Eszközkezelő Zrt.-vel bérleti viszonnyal a pályázó; nincs más lakhatási lehetősége, egyúttal jegyző vagy járási hivatal által megállapított ápolási díjban, vagy saját jogú nyugellátásban, vagy megváltozott munkaképességü személyek ellátásában részesül, vagy családi pótlékra jogosító gyermeket nevel.

A pályázatok elbírálásánál az alábbi feltételeket nagy súllyal vették figyelembe: a bérbeadóval a pályázat benyújtásakor már lakásbérleti jogviszonyban állt a pályázó; Ócsa városában vagy Alsópakonyban élő pályázó; több gyermeket nevelő pályázó és a pályázat benyújtásának időpontja (Pályázati felhívás I., II., 2013).

Az utolsó három pályázati kiírásból minden olyan feltétel hiányzott, ami a beköltözők motiváltságára, a közösségi együttélés szabályaira vonatkozott volna vagy a család önfenntartását írta volna elő. Egyértelmü, hogy ekkor már a Nemzeti Eszközkezelő Zrt. feladata a lakások bérbeadása volt azzal a kiemelt szemponttal, hogy a bérlő biztonsággal fizesse a bérleti díjat. Minden szociális szempont másodlagossá vált.

\section{A lakók: a múlt terhei}

Az instabil, alapok nélküli állapot következtében sok olyan család érkezett új lakóhelyére, akiknek az alapvető létfenntartás is gondot okozott. Ez azért volt kifejezetten meglepö, mivel

\footnotetext{
${ }^{36}$ A 3-5. pályázat következtében már teljes egészében megtelt lakópark folyamatait nem vizsgáltam, mivel ez később következett be, mint ahogy a kutatásom lezárult.
} 
elszegényedése előtt több család szociológiai értelemben alsó középosztálybeli státust töltött be, helyzetük az akkori közösségükön belül rendezett volt. Ez az „új” állapot olyan magatartásformák elöretörését eredményezte, amelyek megszegik a társadalom nagy része által elfogadott formákat.

A kutatás során azt tapasztaltam, hogy a lakóparkba újonnan beköltöző családok ugyan ingóságaikat magukkal tudták hozni, de az identitásukat (szerep, kapcsolat, önkép) csak részben vagy egyáltalán nem. Egyrészt azokat a kulturális alapokat, amelyeket régi közösségükben a mindennapjaik során magukévá tettek, ha át is szerették volna menteni az új közösségbe, nem tudták, mert nem volt meg az a közösség, ami azt addig képviselte. Az elhagyott közösségük intézményrendszerét, szimbólumait, rítusait, de akár a kozmológiáját is itt a régi csoport hiánya miatt nem tudták tovább folytatni, fenntartani. Másrészt ,az előző életükben" kialakult identitásuk, annak teljes szociokulturális repertoárja, az elszegényedésük következtében többnyire már a régi közösségben elveszett, más, idegen társadalmi státusba kerültek, ami a már kialakult identitásuk önértelmezését is befolyásolta.

A terepen töltött egy év és a különböző típusú interjúk elkészítése során majdnem minden család esetében felfedeztem a múltban gyökerező sérülést, krízist, traumát.

Megjelent a családok egy részénél a függőség mint problématerület.

„Már én is gyerekkoromban szipuztam, akkor Technokolt használtunk. De a fiam, ö nem drogos. Ö teljesen tiszta. Itt van a vérképe, tessék, nézze meg!” Az interjúalany fiát pár héttel ezelőtt büntetőjogi eljárás alá vonták drogterjesztésért.

Egy másik család esetében, ahol elváltak a szülők, az anyával beszélgettem. „A párom szomszédol, sokat szokott szomszédolni. Jó régóta nincs neki munkája... Már várjuk a családi pótlékot. Végre lesz egy kis pénz! Én naponta 4-5 órát ülök a számitógép előtt és társalgok idegenekkel és sokat játszom. Meséket nem szoktam olvasni a gyerekeknek. Általában hideget eszünk. Én nagyon szeretem a számitógépet!"

A harmadik családnál az apa alkoholista, de már több hónapja absztinens. Az apa a család minden pénzét korábban az alkoholra fordította. Az első interjú esetében, a fiúgyerek miatt voltam ott, aki több tantárgyból is bukásra állt.

Az interjúalanyok többféle család-, háztartástípusban éltek. Az együtt élő személyek struktúrája alapján különféle konfliktusok generálódtak.

Az egyik vizsgált háromgyerekes családban az apának két vér szerinti gyermeke van, két külön anyától, akikkel nem tartja a kapcsolatot. Az egyik gyermeket sosem, a másikat hat éve nem látta. A férfi elvált szülők gyermekeként nőtt fel. „Holnap megyek biróságra. Nem fizetem a tartásdijat. Ez a baj. Nem fizetem. Miért fizetném? Nem is látom őket, és nevelek helyettük másik hármat. Feljelentett a második feleségem, hogy ütöttem, vertem öt. Úgy nézek én ki, mint aki üti, veri a feleségét?” „A három gyereket, akit most nevelek, sokkal jobban szeretem, mint a sajátjaimat. Találkoztam a három gyerek igazi apjával, aki nem is foglalkozik a gyerekekkel. Megkérdeztük töle az élettársammal, miért nem fizet tartásdíjat? Azt a választ kaptuk, hogy azért nem, mert kefélek a nejével. Én azonnal felraktam öt a falra."

Egy másik családban az anya elvált, jelenleg volt férjével él együtt. „Vannak gondok, de megvagyunk. Nagyjából egy háztartásban élünk, de mindenki mindent külön fizet. Én csak a gyerek miatt vagyok vele együtt. Szerintem az élettársamnak van másik kapcsolata is, de nem érdekel. Ha megkíván, akkor együtt alszunk, egyébként külön. Néha még el is megyünk együtt ide-oda. Akár még nyaralni is. De nem beszélünk egymással." 
Egy másik édesanya azt mesélte, hogy: „18 évesen összeköltöztem a fiam apjával. Újra teherbe estem. Azt mondta a párom, hogy vetessem el, mert neki nem kell vagy kirugdossa a hasamból. Én ezért terhesen inkább elköltöztem. De mivel nem tudtam eltartani a két gyermeket, a kislányt elvették. Nem én nevelem..."

Több interjúalany is beszámolt fizikai bántalmazással kapcsolatos traumákról.

Egy interjúalany az apja bántalmazó viselkedéséről mesélt. „Az apámmal nem beszélek. Szeretem, de nem beszélek vele. Sokszor undoritó dolgokat csinált velem. Összetört mindent, amikor részeg volt. A játékaimat is. Volt, hogy úgy megvert, hogy kék, zöld voltam. Mivel mi szerettük, többször megpróbáltuk visszafogadni, de ö visszaélt a szeretetünkkel. Most is itt vagyunk, nincsen semmi pénzünk, de ö nem ad semmilyen anyagi támogatást. Van két kutyánk. Muszáj, hogy legyen egy kis élölény, aki szeret minket. Amikor engem és anyukámat vert, aki látta, próbált minket megvédeni. Sokszor verekedtek az apukámmal."

Egy családdal történt beszélgetés során egy anya elmesélte a tetoválása történetét. „Intézetben nöttem fel. A nagyokkal bandáztam, drogoztam, ittam... Ahogy megszülettem, intézetbe kerültem. Anyukám, apukám alkoholista volt. Kilencen vagyunk testvérek. Hárman ismerjük egymást. Néha elmentem apukámhoz, de csak egy napig maradtam ott. Aki a tetoválásaimat készitette, egy 16 éves fiú volt. Már 12 évesen volt köztünk szexuális kapcsolat. Utána már folyamatosan éltünk szexuális életet. 14 évesen volt az elsö abortuszom."

Egy másik esetben egy nemrég beköltözött családhoz látogattunk el az egyik szociális munkással. Az apának 8 általános iskolánál alacsonyabb iskolai végzettsége volt. Az anyáról egy későbbi, négyszemközti beszélgetésen kiderült, hogy fiatal korában prostituált volt. Három gyereket neveltek, a harmadikkal akkor volt várandós az anya. A 6 éves fiú az Éjjelnappal Budapestet nézte a televízióban. A kislány odafutott hozzánk, és azt mondta: „ $A z$ apukám ma kezdett el dolgozni, és hozott nekem egy rágót!’ Nagyon örült neki. Megkérdezte a szociális munkás, hogy van-e valamire szükségük. Azt a választ kaptuk: „Ismerek sok mindenkit, nincsenek problémáink."

Megtalálhatóak voltak a munka világához kötődő problémák is a megkérdezett családoknál. Az egyik lakó több hónapja dolgozott külföldön. Nagyon ritkán tudott hazajönni a gyerekeihez, családjához, de pénzt még nem kapott. Megkérdeztem tőle, hogy be van-e jelentve, van-e szerződése? Azt a választ kaptam: „Nincs, de megígérték, minden rendben lesz. Ugyan már félmillióval tartoznak és már el sem tudom érni a munkaadómat, de biztos minden rendben lesz." Fél évvel később megkérdeztem, hogy megkapta-e a pénzét. A válasza nemleges volt, már senkit sem ért el, de még mindig bizakodott.

Egy másik esetben egy értelmiségi anyával beszélgettem, aki tökéletesen tudott angolul. Elmondta, hogy reggel 5.10-kor indul otthonról és este 20.30-kor ér haza. ,Ez minden nap igy megy. Kicsivel több, mint 100000 Ft van a fiamra és rám. Ebböl a pénzböl nagyon nehezen élünk meg ketten.” Megkérdeztem, hogy tökéletes angoltudással és felsőfokú végzettséggel, miért nem vált munkahelyet? A válasza az volt, hogy „,nem tudom, nekem csak így megy, nem tudom jobban irányitani az életemet”.

Több családban is fontos pontként jelent meg a státusszimbólumaik fenntartásának igénye.

„A pénzt nem tudjuk beosztani. Kevés pénzböl élünk. A fiú most ballagott, beadtam zálogba a telefonomat, hogy tudjunk neki ünnepséget tartani. Ez mindig így szokott lenni." A lakásban, ami kevés bútor volt, az mind régi és kopott volt. 
Egy másik családban történt. „Hát én itt ki sem teszem a lábam! Az emberek nem jól lettek kiválasztva. A lányomat már ide sem engedem jönni. Hát itt milyenek a körülmények? Az utolsó öt család indiánokból áll. A mostanában beköltözöttek vissza sem köszönnek."

Harmadik esetben egy megbeszélt találkozóra egy család a helyzetükhöz képest jobb minőségü autóval érkezett meg. Amikor kiszálltak, kifejezetten jól öltözöttek voltak, egy jól szituált család benyomását keltették. Bementünk a házba. A beszélgetés során kiderült, hogy a gyerekek Pestre járnak iskolába, az apa csak annyit mondott, hogy nem szeretné, ha a gyerekei ide járnának a helyi iskolába, és azt sem szeretné, ha részt vennének az itteni foglalkozásokon. Kinyitották a hütő ajtaját, és az a telepen másutt is tapasztaltaknak megfelelően üres volt. Azon tanakodtak, mi legyen a vacsora. A házukat már elárverezték, de még mindig több millió forint adósságuk volt.

A családok között megfigyelhetőek voltak etnikai hovatartozás mentén kialakuló konfliktusok.

Egy előre megbeszélt időpontban látogattam el egy családhoz. A házon árpádsávos zászló. A kapura kiírva: „Ha szereted a békességet, akkor csengess és várj! Ne lépj be!” Az udvaron egy német juhászkutya. Az anya kinyitotta az ajtót. Most ugrott be, hogy vele többször találkoztam már, de sosem köszönt vissza, mikor köszöntem neki. Feldúltan lépett ki kezében egy nagy késsel. „Hárommilliót költöttünk a házra és a telekre, csak ezért nem megyünk el. Utáljuk a cigányokat, és abból most itt nagyon sok van. A helyi segitöket is utáljuk. Nem mondok önnek semmit, mert azt ök is tudni fogják.” Közölte velem, hogy távozzak, majd megfordult és köszönés nélkül bement a házba.

Az út szélén beszélgettem egy alkalommal több helyi lakossal, miközben 8-14 év körüli fiatal gyerekek labdáztak az úton. Az egyik lakó arra jött az autójával. Lelassított, de nem állt meg. A gyerekek szétfutottak az út szélére, de az egyik háttal állt, nem látta az autót. Az autót vezető annyiban változtatott a haladási irányán, hogy a gyerek ne kerüljön az autó alá, de szándékosan elütötte úgy, hogy a gyereket oldalra kitolta, és a gyerek elesett. Megállás nélkül továbbhajtott. Erről a lakóról és családjáról az egyik család úgy nyilatkozott, hogy „nagy probléma van velük, rasszisták. Már nem elöször fordul elö, hogy veszélyezteti az itt lakókat az autójával."

Egy cigány családdal beszélgettem. Megkérdeztem tőlük, hogy hogy nevezhetem őket, cigánynak vagy romának? Azt a választ kaptam, hogy: „Mindegy. A lényeg, ahogyan mondja. Egyébként is, voltunk mi már itt indiánok, mocskok, rohadt cigányok. Nehéz volt, de most már elfogadnak. Nekünk senkivel nincs problémánk." Büszkén mutatta nekem a gyermeke oklevelét, amit az iskolában kapott.

A lakóknak minden évszakban speciális problémákkal kellett szembenézniük. A kutatás ősszel kezdődött, talán ekkor kellett a legkevesebb kihívással szembesülniük. Gondot okozott, hogy nagyon nehéz volt az ősz során ingadozó hőmérsékletben megfelelő módon füteni a lakásokat, mivel a fatüzelésü kályhák nem szabályozhatók.

Télen komoly gondot jelentett, hogy a hideg miatt a gyerekek és a fiatalok sem tudtak a szabadban lenni, és a segítő szervezet által müködtetett 50 négyzetméteres házon kívül semmilyen közösségi tér nem volt a közelben. A közösségi ház leginkább akkor tartott nyitva, amikor a közösség a legkevésbé igényelte, hétköznap, napközben. A gyerekek ebben az időszakban óvodában, iskolában voltak. Hétvégeken a közösségi ház zárva tartott. 
Tavasszal esős és szeles volt az időjárás. Ekkor tapasztaltam meg a rosszul kiválasztott helyszín több következményét. Mivel nem voltak fák és dombok, a szél teljesen átfújta a települést, és a csapadékvíz elvezetése is megoldatlan volt. Ugyan készítettek a kivitelezés során esőelvezető árkokat, ám az árkok csak felfogták az esővizet, nem vezették azt, így rendszeresen megteltek. Ebben az évszakban is hiányzott a fiataloknak egy közösségi hely, ahol együtt tölthették volna az időt. Erre senkinek a háza nem volt alkalmas, hiszen minden ház alapvetően kis alapterületü, így túlzsúfolt volt.

Nyáron a legnagyobb problémát a legyek okozták. Sokat jártam a környéket, hogy rájöjjek, mi is a legyek tömeges jelenlétének oka. Elöször találtam egy nagy trágyarakást a település közelében. Kiderült, hogy Ócsa város az elmúlt években mindig itt tartotta a trágyát. Ezt később elvitték, valószínüleg a legyekkel kapcsolatos bejelentések következtében, ám a legyek száma nem csökkent. Több környékbelivel beszéltem, és kiderült, hogy a lakóparkot minden oldalról körülvevő gyümölcsösöket, mezögazdasági területeket folyamatosan trágyázzák, trágyalével permetezik. A felnőttek mindent megtettek a legyek elleni védekezésért, ezért szúnyoghálókat és légypapírokat vettek, de azon túl, hogy ezek a $80 \mathrm{~cm}$-es légypapírok két-három nap alatt teljesen megteltek, a helyzet semmit sem változott.

Nyáron a másik kiemelt problémának az árnyék hiánya bizonyult. A 2014-es nyár az ott lakókhoz kifejezetten kegyes volt, mert az elmúlt évek több hétig tartó hőhullámai elmaradtak, de így is érezhető volt, hogy milyen nehézségeket okoz az árnyék hiánya. Egyetlenegy fa sem volt, ami két méternél magasabb lett volna. Ezért a gyerekek kénytelenek voltak délelőtt 10 órától este 6-ig bent lenni a házakban. Majd 6 óra után, ahogy a hőmérséklet csökkent, mint egy méhkas eső után, úgy kelt életre a település; és a gyerekek, fiatalok és felnőttek szinte kirajzottak a lakásokból. A tizen-huszonéves fiatalok, akik egész nap benn ültek a házban és várták, hogy enyhüljön az idő, miután végre kijutottak, többnyire éjfélig nem csináltak mást, mint a település hat aszfaltozott útján a lakóházak között sétáltak, „, hangoskodtak”, ,, ricsajoztak”. Ez viszont az idöseket este 9 után kifejezetten zavarta, hiszen nem tudtak így nyugodtan aludni. Az ablakokat nem lehetett a meleg miatt becsukni, így minden behallatszott, ami mindennapi vitákat, komoly konfliktusokat szült a közösségen belül.

\section{Végkövetkeztetések}

Az úgynevezett devizahitel-probléma elsődleges oka a jövedelmi viszonyokban és a magyarországi lakáspolitika, valamint lakásgazdálkodás müködésében keresendő.

A lakásépítések száma az 1990-es évektől kezdődően csökkenni kezdett, majd 1999-re összességében már csak mintegy 20000 lakást építettek évente.

Ezt a problémát kívánta az első Orbán-kormány orvosolni az életbe léptetett jogszabályi változtatásokkal. Ezt követően a Medgyessy-kormány, látva a kamattámogatás költségvetésre nehezedő egyre nagyobb súlyát, ezt a jogintézményt folyamatosan szükítette, majd megszüntette, viszont megengedte, hogy helyébe a sokkal kockázatosabb devizaalapú hitelezés lépjen. 2008 őszén hazánkat is elérte a gazdasági válság, és a várható kockázatokat valóssá tette. Ezáltal nemcsak az eredeti közpolitikai probléma megoldására tett lépések vallottak teljes kudarcot, hanem ha a 2012-es év adatait nézzük, az is látható, hogy ekkor összesen 10560 új lakáscélú ingatlan kapott használatbavételi engedélyt, ami az elmúlt 100 év legkisebb számú lakáscélú ingatlanépítését jelzi. Emellett a több kormányon átívelö, nem megfelelö lakáspolitikai intézkedések újabb, az elöbb ismertetett közpolitikai kudarcnál is nagyobb, és rövid távon biztosan súlyosabb, közpolitikai problémát eredményeztek. Ez pedig, 
a hitelből vásárolt lakáscélú ingatlannal rendelkezők és családjuk életét rendkívül nagymértékben megnehezítette.

Arra a kérdésre, hogy a ki felelős leginkább a kialakult helyzetért, a hitelfelvevők, a bankok, az aktuális kormány, az országgyülés, a PSZÁF vagy az MNB, a válasz: mindenki.

A 2009-től kialakult helyzet értékelésénél alapvető kérdés, hogy a közpolitikai kudarc, mely a hitelt felvevők általam vizsgált csoportját szorította, orvosolható-e az adófizetők pénzébőll? Terhelhetö-e olyanokra, akik vagy kellő bölcsességgel és óvatossággal nem vettek fel hitelt, vagy akár anyagi helyzetük miatt nem tudtak felvenni hitelt annak nagyon „hívogató” feltételei ellenére sem, vagy akár csak azokra, akik nem kívántak élni a hitelfelvétel lehetőségével? Szabad-e, lehetséges-e közvetve más társadalmi csoport rossz, hibás döntéseik következtében kialakult problémáját részben rájuk hárítani, terhelni? Ennek a morális kérdésnek az eldöntése egy külön dolgozatot igényelne.

Az is fontos kérdés, hogy az államnak van-e joga már megkötött magánjogi szerződésekbe belelépni, azok tartalmát bírósági állásfoglalás, ítéletek nélkül megváltoztatni, szűkíteni, még ha ezzel a társadalom igen jelentős részét érintő drámai elszegényedést próbálták is megakadályozni.

Az ismertetett kormányzati intézkedések alapján látható, hogy a kialakuló újabb és újabb „megoldásokat” követő állapot, folyamatosan mélyülő, ismételt közpolitikai kudarchoz vezetett, a meghozott kormányzati intézkedések és az országgyülés által elfogadott törvények nem érték el céljukat.

Mint ahogy a szociális családiház-építési program sem felel meg a kormányzat által felvázolt célnak. Az elszegényedett és ellehetetlenült családokat egy már szegregált területre költöztették be. A feltételek nem voltak adottak sem a munkavállalásra, sem a helyben történő munkavégzésre, önfenntartásra. A környéken nem voltak szabad munkahelyek, a távolabbi munkahelyek megközelítése rendkívül körülményes volt, az önfenntartáshoz a telkek mérete kicsinek bizonyult, a földminőség rendkívül rossz, a gondozáshoz szükséges locsoláshoz az öntözést nem oldották meg, a munkaeszközök tárolásához, a kisállatok tartásához szükséges épületek hiányoztak. Az Index tudósítása szerint 2016-ban a telepen 350 fö élt, a lakók mintegy fele gyerek. ${ }^{37}$ A kisebb gyermekek számára az óvodai, bölcsődei elhelyezés nem volt megoldott. Ugyan fokozatosan próbálták orvosolni a hiányosságokat, azóta többek között kutakat fúrtak, sürítették a buszjáratokat, tüzifatárolókat készítettek, és hiába tudtak a lakók relatíve jó minőségű lakásokba költözni, a minőségi, boldog élet lehetőségei nem voltak adottak számukra.

Kezdetben egy karitatív szervezet segített a helyszínen a közösségépítésben, beilleszkedésben, a gyerekeknek játszóházat müködtettek, segítettek az ügyek intézésében, de mára befejeződött a tevékenységük.

A kudarcot a kormány is felismerte és az 1558/2016. (X. 13.) Korm. határozattal a szociális családiház-építési programról szóló 1279/2011. (VIII. 10.) Korm. határozatot hatályon kívül helyezte. A lakópark maradt, ami volt, egyfajta zárvány, elkülönülve a környezetétől.

\footnotetext{
${ }^{37}$ https://index.hu/gazdasag/bankesbiztositas/2016/10/18/ocsa_devizahitel_lakopark/.
} 


\section{Szakirodalmi hivatkozások:}

ÁSZ, Állami Számvevőszék (2009): Jelentés a lakástámogatási rendszer hatékonyságának ellenörzéséröl (forrás:

https://www.asz.hu/storage/files/files/\%C3\%96sszes\%20jelent\%C3\%A9s/2009/0908j000.pdf ?ctid=732) (letöltés: 2018. 09. 18.).

BMK Zrt. (2012): Ajánlattételi Dokumentáció, Szociális családiház-épitési program.

FARKAS J., HEGEDÜS J., SZÉKELY G.-né (2004): Lakáshelyzet, lakástámogatások, 1999_ 2003 (forrás: http://old.tarki.hu/adatbank-h/kutjel/pdf/a797.pdf) (letöltés: 2018. 03. 29.).

KSH: 3.7.4. Lakáscélú hitelek (2001-)(1/2) (forrás:

http://www.ksh.hu/docs/hun/xstadat/xstadat_eves/i_zrh001a.html) (letöltés: 2018. 09. 18.).

KSH: 3.7.4. Lakáscélú hitelek (2001-)(2/2) (forrás:

http://www.ksh.hu/docs/hun/xstadat/xstadat_eves/i_zrh001b.html) (letöltés: 2018. 09. 18.).

KSH: 3.7.6 Lakáscélú hitelek (forrás:

http://www.ksh.hu/docs/hun/xstadat/xstadat_evkozi/e_zrh001.html)

(letöltés: 2018. 09. 18.).

KSH: Lakásviszonyok az ezredfordulón (forrás:

https://www.ksh.hu/docs/hun/xftp/idoszaki/pdf/lakviszezr.pdf) (letöltés: 2018. 09. 18.).

KSH: Magyar Statisztikai Évkönyv 2011 (forrás:

http://www.ksh.hu/docs/hun/xftp/idoszaki/evkonyv/evkonyv_2011.pdf) (letöltés: 2018. 09.

18.).

Magyar Bankszövetség (2012): Beszámoló a Bankszövetség 2012. III. negyedévi tevékenységéröl, Budapest.

MBVK, Magyar Bírósági Végrehajtói Kamara (2012): III. negyedéves jelentés.

MNB, Adatok, idősorok, VII. árfolyam (forrás: https://www.mnb.hu/statisztika/statisztikaiadatok-informaciok/adatok-idosorok/vii-arfolyam) (letöltés: 2018. 09. 18.).

MNB: Idősorok (forrás: https://www.mnb.hu/felugyelet/idosorok) (letöltés: 2018. 09. 18.). Nemzeti Eszközkezelő Zrt. (2013): Pályázati felhívás I. Az Ócsán megvalósuló „Szociális családiház-építési program" keretében lakóparkba költöző családok kiválasztására (I. ütem). Nemzeti Eszközkezelő Zrt. (2013): Pályázati felhívás II. Az Ócsán megvalósuló „Szociális családiház-építési program" keretében lakóparkba költöző családok kiválasztására (II. ütem). PSZÁF (2012): Gyorselemzés a végtörlesztésről. In PSZÁF Hírlevél 2012. március (forrás: https://www.mnb.hu/letoltes/hirlevel-2012-03-marcius-final.pdf) (letöltés: 2018. 09. 18.).

\section{Jogszabályi hivatkozások:}

106/1988. (XII. 26.) MT rendelet

1994. évi LIII. törvény

1995. évi XCV. törvény 
1/2000. (I. 14.) Kormányrendelet

2001. évi XCIII. törvény

12/2001. (I. 31.) Kormányrendelet

88/2001. (VI. 15.) Kormányrendelet

138/2001. (VII. 31.) Kormányrendelet

79/2003. (VI. 6.) Kormányrendelet

221/2003. (XII. 12.) Kormányrendelet

2010. évi XCVI. törvény

2011. évi LXXV. törvény

2011. évi CXVI. törvény

110/2011. (VII. 4.) Kormányrendelet

156/2011. (VIII. 10.) Kormányrendelet

257/2011. (XII. 6.) Kormányrendelet

265/2011. (XII. 13.) Kormányrendelet

1279/2011. (VIII. 10.) Kormányhatározat

1434/2011. (XII. 13.) Kormányhatározat

431/2012. (XII. 29.) Kormányrendelet 